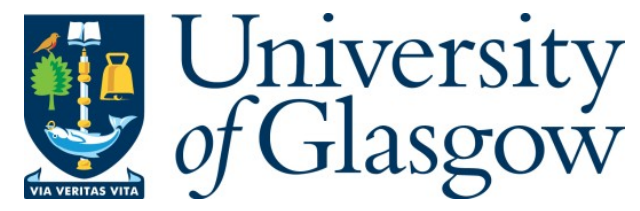

Preene, M., and Younger, P.L. (2014) Can you take the heat? - Geothermal energy in mining. Mining Technology, 123 (2). pp. 107-118. ISSN 1474-9009

Copyright (C) 2014 Maney Publishing

A copy can be downloaded for personal non-commercial research or study, without prior permission or charge

Content must not be changed in any way or reproduced in any format or medium without the formal permission of the copyright holder(s)

When referring to this work, full bibliographic details must be given

http://eprints.gla.ac.uk/96047

Deposited on: 18 August 2014

Enlighten - Research publications by members of the University of Glasgow http://eprints.gla.ac.uk 
Title

\section{CAN YOU TAKE THE HEAT? - GEOTHERMAL ENERGY IN MINING}

\section{Authors}

${ }^{*}$ M Preene ${ }^{1}$ and P L. Younger ${ }^{2}$

${ }^{1}$ Principal

Golder Associates (UK) Limited

Golder House, Station Road, Tadcaster,

Leeds, LS24 9JF, UK

(*Corresponding author: mpreene@golder.com)

${ }^{2}$ Rankine Chair of Engineering, and Professor of Energy Engineering

School of Engineering,

University of Glasgow

Glasgow, G21 8QQ, UK

\section{Revision 1}

Revision 14 March 2014 


\title{
CAN YOU TAKE THE HEAT? - GEOTHERMAL ENERGY IN MINING
}

\author{
ABSTRACT \\ In 2013 there are less than 20 documented examples of operational geothermal systems on mine sites \\ worldwide. This is surprising, since on remote mine sites, where fuels may have to be shipped in over great \\ distances, heating and cooling from low-enthalpy geothermal sources may have a significant advantage in \\ operational cost over conventional energy sources.
}

A review of factors affecting the feasibility of geothermal systems on mining projects has been undertaken, and has identified the possible configurations of geothermal systems suitable for the exploration, operational and closure phases of mine development. The geothermal opportunities associated with abandoned or legacy mines are also discussed. The potential categories of heat reservoirs associated with mine sites are: natural ground; backfilled workings; mine waste, dewatering pumping; and flooded workings/pit lakes.

The potentially lower operational costs for heating and cooling must be offset against the capital cost of a geothermal system. The focus for mine operators should therefore be on identifying at feasibility stage those projects where conditions are favourable for geothermal systems, where the potential risks are understood, and where the economics are likely to be beneficial, where geothermal systems can be established while minimising additional capital costs.

\section{KEYWORDS}

Energy, Geothermal, Minewater

\section{INTRODUCTION}

The use of geothermal technologies to extract heat energy from the sub-surface environment, to provide heating and cooling or to generate electricity, is well established outside of the mining industry, yet to date it has seen relatively little uptake within the sector. As it relies on the same blend of geological and engineering skills which mining demands, this omission is rather puzzling, and begs the question whether it represents a considered rejection or merely oversight. In appropriate geological settings, with the correct engineering, geothermal energy can be an economic source of low carbon energy, able to displace traditional fossil fuelbased energy sources, either for use within a mine, for supply to living quarters or working areas on mine sites or for sale to third parties. This paper examines the proposition that the mining industry is ripe for a significant expansion of geothermal energy use.

Conventionally, geothermal heat energy in soils and rock (and associated geofluids such as groundwater or brine) is exploited via drilled wells, via buried 'ground collectors' (typically looped heat-exchange pipework), from pumped groundwater or from surface water bodies such as lakes. Unfortunately, while the unit cost per generated kilowatt hour $(\mathrm{kWh})$ can be significantly less than that of comparable traditional energy sources, a geothermal system typically requires significant up-front capital cost to construct the necessary geothermal wells or ground collectors. This capital expenditure is required before a single kWh of energy can be generated, and is probably one of the factors why geothermal systems have not been implemented in a wider range of settings and by a wider range or organisations.

However, in the case of the mining industry, much of the work required to establish geothermal infrastructure is already undertaken for other purposes. The mining industry routinely: constructs major structures that penetrate the subsurface (open pits, underground roadways); pumps groundwater as part of dewatering operations; and may leave behind artificial water features (pit lakes or flooded workings). An obvious opportunity is to use these engineered features associated with mine sites, where the capital and operational costs are already committed, to exploit heat energy from geothermal sources. Over the last decade, there have 
been considerable theoretical and academic studies of the potential for the exploitation of geothermal energy via mine infrastructure (see for example: Malolepszy et al 2005; Digges La Touche and Preene 2011; Parker 2011; Wieber et al 2012). However, based on published information, to date only a very small number of mining-related geothermal systems have been implemented worldwide (Table 1). Additionally, the authors are aware of several proposed projects to harness geothermal energy from mines (one of the most notable of which is the scheme to provide energy to the city of Yellowknife in the Northwest Territories of Canada; Ghomshei 2007), but many of these are in early stages of development or have become stalled or have even been abandoned. Undoubtedly, the effects of the Global Financial Crisis may have played a part in restricting the investment available for such schemes, but it is also possible that technical and environmental factors, as well as the perceived risks, have influenced the lack of uptake of mining geothermal systems.

On the premise that geothermal systems are not new and are not based on radical technologies, the current paper is intended to promote technology transfer from outside the mining industry by discussing the technologies used to exploit geothermal heat energy, and by identifying the conditions where the exploitation of geothermal energy may be feasible and economic. The engineering challenges, key risks and potential environmental impacts will be highlighted, and the possible future role of geothermal energy in mining will be discussed, As it is rare that mines access water hot enough $\left(>85^{\circ} \mathrm{C}\right)$ to generate electricity using binary power plants, the focus of this paper is on lower-enthalpy systems which can be exploited (with or without the aid of heat pumps) for direct heating / cooling purposes.

\section{DRIVERS FOR EXPLOITING MINING GEOTHERMAL ENERGY}

There are three principle drivers for exploitation of geothermal energy:

1. Financial savings. All mining operations use heat energy, to a lesser or greater degree influenced by the local climate and the type of mining and processing operation. The energy costs associated with heating maybe substantial. Geothermal energy can potentially provide heat at lower unit costs than conventional fuels, thereby reducing operating costs.

2. Environmental benefits and Corporate Social Responsibility (CSR). Geothermal systems are classified as low carbon energy sources. Typically heat from geothermal systems will be used to displace heat derived from conventional fossil fuel sources; use of geothermal energy will reduce carbon emissions, which is in line with typical CSR objectives.

3. Gaining benefit from closed and legacy mines. Flooded mine workings and open pits can be significant reservoirs of geothermal heat. If these heat reservoirs are exploited this can generate new revenue streams for mining companies, and potentially support the sustainable development of communities associated with closed mines.

It is important to realise that the geothermal potential and associated risks and challenges will be unique to each project - geothermal energy is not a panacea for all mining projects, viability will depend on diverse factors including geology and existing infrastructure. Where geothermal energy is being considered a feasibility study is likely to be required, addressing the factors outlined later in this paper.

\section{PRINCIPLES OF LOW-ENTHALPY GEOTHERMAL SYSTEMS}

In concept, low-enthalpy geothermal systems are very simple. Three interconnected elements are required to allow geothermal energy to be exploited (Figure 1):

a) A heat source or heat reservoir (a stratum of soil or rock, a geologic aquifer or a body of surface water such as a pit lake). To be exploitable, a heat reservoir typically needs to contain permeable pathways or connections (e.g. natural fissures and fractures or artificial features such as mine workings) and contain a mobile geofluid (most commonly groundwater, but also brine or - in high enthalpy systems - steam);

b) A heat transfer or energy conversion system (heat exchangers, heat pumps or - in high enthalpy systems - electrical generation equipment); and

c) An energy load (i.e. a demand for the energy produced by the system). 
There are two principal types of geothermal systems - open loop and closed loop - differentiated by the type of infrastructure (termed the "ground collector") used to extract heat from the ground and pass it to the heat transfer/energy conversion system.

- $\quad$ Open loop systems (Figure 1a) extract groundwater from the heat reservoir, via ground collectors which typically take the form of wells or intakes. The water is then passed through the heat transfer system before being disposed of (at different temperature to when it was extracted) either to waste or by reinjection into the source reservoir. If the water is re-injected it can allow an open loop system to operate as a zero net extraction system.

- $\quad$ Closed loop systems (Figure 1b) differ from open loop systems in that they do not extract groundwater from the heat reservoir. Instead, the ground collector takes the form of a loop of pipework in intimate contact with the heat reservoir through which a heat transfer fluid is circulated. As the heat transfer fluid travels through the ground collector it gains or loses energy from the reservoir. This heat energy is then passed to the heat transfer system at the surface.

Figure 1 shows a typical configuration whereby the groundwater from the heat reservoir is passed through a heat transfer system (typically a conventional heat exchanger) and heat energy is then circulated to the various heat demands via a secondary loop. This approach is adopted because the groundwater pumped from the reservoir may have a complex chemical composition, resulting in aggressive corrosion conditions, risk of chemical precipitation, or release of hazardous mine gases. The use of a secondary loop reduces the amount of equipment exposed to the aggressive groundwater and can allow the pumped groundwater to remain pressurised, thereby reducing the risk of degassing, chemical precipitation and clogging. The secondary loop can therefore circulate 'clean water' and equipment connected to the loop can be designed for less onerous chemical conditions, saving capital costs.

Geothermal systems can also be categorised is based the temperature of the source reservoir. Higher temperature reservoirs (greater than about $85^{\circ} \mathrm{C}$ ) have the potential to be exploited to produce electricity, while lower temperature reservoirs can only be exploited for heating (and indeed for cooling). The vast majority of mines will be in geological conditions where the reservoir temperatures are not high enough to allow electricity to be generated. However, occasionally hot fluids are generated in dewatering systems which may allow electricity generation; this is especially likely to occur in tectonically active regions. Williamson and Vogwill (2001) report that the Lihir Gold Mine in New Guinea had to manage water at temperatures of 90 to $100^{\circ} \mathrm{C}$ and Popielak et al (2013) describe groundwater at 70 to $160^{\circ} \mathrm{C}$ in the Cerro Blanco underground mine in Guatemala.

A more complete background to geothermal systems used to generate electricity can be found in Dickson and Fanelli (2003). Geothermal systems used to provide heating and cooling are described in Banks (2012).

\section{KEY POTENTIAL RISKS ASSOCIATED WITH LOW-ENTHALPY GEOTHERMAL SYSTEMS}

There are a range of potential risks associated with low enthalpy geothermal systems, the most significant of which are discussed below. The investigation of the relevant issues is a key part of the feasibility assessment described later in this paper.

i. Heat resource risk: Is the heat resource in the reservoir adequate in terms of the quantity of usable heat (in MJ) and the quality of the heat (e.g. peak temperatures). This risk can be quantified by relatively conventional programmes of hydrogeological drilling and modelling.

ii. Heat accessibility risk: Is there adequate hydraulic connectivity in the heat reservoir and do structures which can function as ground collectors already exist or can they easily be constructed with a high certainty of thermal output? By this measure, sites which already include dewatering pumping or flooded pits or workings have readily accessible and quantifiable heat and would be considered low risk. 
iii. Environmental and regulatory risk: Is there a significant risk that a geothermal system may cause unacceptable environmental impacts or may be constrained by regulatory issues? Based on experience in other industries, this risk can typically be quantified and mitigated by good design and planning.

iv. Operational and heat continuity risk: Is there a significant risk that operational problems may reduce the system efficiency during its life, or even lead to interruption in heat supply? Examples of operational problems include system corrosion, encrustation or clogging due to aggressive minewater chemistry, or the risk of excessive reductions in heat reservoir temperature as a result of high heat extraction rates. This risk can be quantified by hydrogeological and geochemical modelling.

When assessing how these risks may be perceived within the mining industry, it is important to realise that the broadly same risks apply to geothermal applications in other industries. Over the last decade there has been a significant increase in the uptake of low-enthalpy geothermal systems in commercial buildings (Wang et al., 2007). Property developers are little different to the mining industry in their desire to manage risk and reliably obtain adequate return on capital invested. The track record suggests these risks are not perceived as barriers, but instead act as a road map for studies and investigations for potential applications.

\section{FACTORS AFFECTING THE FEASIBILITY OF LOW-ENTHALPY GEOTHERMAL SYSTEMS}

The stages in assessing the economic feasibility of a potential geothermal system on a mining project are little different to assessing the feasibility of extracting a mineral product, except the raw product to be extracted is heat, which is then processed (or converted) into usable forms of heating and cooling. The key steps are outlined below.

\section{Identify and Determine the Size and Key Parameters of the Heat Reservoir}

The feasibility of a mine-related geothermal system is dominated by the properties of the heat reservoir. If the reservoir does not have suitable properties then even the highest standards of engineering will be of little benefit to producing viable energy. Three key parameters must be considered: the presence of mobile groundwater; the total quantity of accessible heat; and peak temperatures available at the point of heat transfer or energy conversion. Pumping trials and numerical modelling can play an important role in assessing the values of these parameters on a specific site.

Presence of Mobile Groundwater

Although geothermal heat reservoirs can exist without mobile groundwater - the so called "hot dry rock" reservoirs (Brown et al 2012) - in the vast majority of cases for a geothermal heat reservoir to be commercially exploitable, extraction or re-injection of fluids must induce significant groundwater flow. Outside of the mining industry, groundwater flow delivering heat to or from ground collectors is primarily through the natural permeable features (fractures, fissures, interconnected pore spaces) within the stratum, which are connected to the surface via ground collectors. The advantage of mining applications of geothermal systems is that workings (both underground and open pit) below groundwater level will provide enhanced permeability within the reservoir and may be suitable for use as ground collectors. Hydrogeological studies, often including numerical modelling and pumping tests, are a key element of any assessment of the potential for geothermal exploitation at a mine site.

Peak Temperatures Available at the Point of Heat Transfer or Energy Conversion

The maximum temperature of the fluids that can be extracted from open loop systems or circulated in closed loop systems will determine the possible means of exploitation for energy supply:

- $\quad$ Less than approximately $35^{\circ} \mathrm{C}$ : Suitable for exploitation for heating and/or cooling by either heat pumps or direct use by heat exchangers; and

- 35 to approximately $85^{\circ} \mathrm{C}$ : Suitable for exploitation for heating by direct use (heat exchangers). The key temperature is the maximum available at the point of heat transfer (e.g. heat pump or heat exchanger), which may be lower than the observed static temperature in the geothermal reservoir, especially if groundwater 
is circulating rapidly in the reservoir and has little residence time to absorb heat before it is pumped to the surface.

Total Quantity of Recoverable Energy

The total quantity of heat in Joules (J) potentially available from a geothermal reservoir is typically assessed by determining the effective volume of the heat reservoir, and calculating the heat that can be exchanged as a result of raising or lowering the reservoir temperature by $\Delta \mathrm{T}$. For systems that involve flowing fluid (such as pumped dewatering systems) the calculation is based on raising or lowering the temperature of the flowing fluid by $\Delta \mathrm{T}$. Methods of calculation are given in Appendix 1.

However, the total quantity of heat available does not tell the full story. It is important to determine the possible sustainable rates of heat extraction in Watts (W), defined as Joules per second. Geothermal reservoirs exist at their current temperatures in response to existing heat inputs and outputs which include solar flux on the ground surface, geothermal flux from depth and heat movements associated with natural groundwater flows. In most cases the artificial extraction of heat at any commercially viable rate will affect the heat balance in the reservoir and over time, temperatures will fall. The greater the rate of extraction the quicker reservoir temperatures will fall.

Falls in reservoir temperatures are important for two principal reasons. Firstly, there will be a 'cut-off temperature' below which the selected heat transfer technology will not operate efficiently. High rates of heat extraction may result in the cut-off temperature being reached in early years of operation, curtailing the life of the usable heat resource. Secondly, any significant temperature reductions in the reservoir temperature increase the risk of adverse environmental effects.

\section{Understand the Market for, and Value of, the Energy which can Potentially be Extracted}

Without a viable end use there can be no demand and any extracted energy has no value. An essential step in feasibility studies is the identification of end uses, which may be on the mine site or off site. It is important to realise modern technology, including heat pumps, can allow heat energy extracted from mines to be used for both heating and for cooling. Therefore, geothermal systems are relevant to mine sites in cold, temperate and hot climates.

\section{Determine the Necessary Engineering Infrastructure}

Once a geothermal heat reservoir has been identified and matched to a potential market for heating/cooling, it is necessary to determine the infrastructure required to extract the proposed rates of heat. Infrastructure may include:

- $\quad$ Ground collectors. In some cases (for example flooded mine shafts, or existing dewatering systems) heat energy can be exploited from mine sites without the need for the construction of ground collectors. However, some schemes will require the construction of new ground collectors in the form of wells or closed loop circulation systems. The selection and sizing of ground collectors is fundamental to the design of geothermal systems.

- $\quad$ Pumping infrastructure. Almost without exception, pumping of fluids is an essential part of the operation of geothermal systems. This can be either extraction of groundwater from wells and shafts or circulation of heat transfer fluid through closed loop ground collectors. Optimisation of pumping systems is important to reduce operating costs and minimise parasitic loads which increase operating costs and reduce net energy output.

- Water disposal infrastructure. Open loop systems produce a waste stream of groundwater that is either disposed of to surface water or by re-injection and recirculation into the geothermal reservoir. Where the flowrate of water to be disposed of is greater than for the conventional mine operation, there will be a requirement for infrastructure to allow the fluid to be transferred without causing flooding or other environmental impacts. 
This stage of project development may require field trials to help support the sizing and location of the required infrastructure.

\section{Identify the Potential for Significant Environmental Impacts}

Just as the development of a new mineral extraction must consider the potential for environmental impacts (both positive and negative), so the development of a geothermal scheme must also consider environmental impacts. It also important to recognise that there may be positive environmental effects in terms of facilitating, for example, new employment opportunities, improving local communities by improving availability of heating/cooling, and reduction in carbon emissions.

\section{Assess the Overall Feasibility of a Geothermal System}

The above aspects of a potential geothermal scheme need to be combined to allow the feasibility and economic viability to be assessed. The design of the ground collectors and pumping infrastructure will have a major influence on the CAPEX and OPEX. As described elsewhere in this paper, each application of geothermal energy on mining projects will effectively be unique. It is therefore difficult to generalise on likely CAPEX and OPEX costs. Outside of the mining industry, data on low enthalpy geothermal systems indicates CAPEX in the range US\$2,000 to US\$3,300 per $\mathrm{kW}$ installed capacity (excluding end user heat distribution systems) and OPEX in the range US $\$ 0.08$ to US $\$ 0.11$ per $\mathrm{kWh}$ of heat delivered (2013 costs). As a starting point these could be used to provide order of magnitude cost estimates at early feasibility stage.

The anticipated energy yield and market value will allow the project cashflow to be estimated. Of course financial assessment is only one criterion to determine whether a scheme should be developed. Geothermal schemes have the potential to reduce the consumption of conventional energy sources, and hence reduce carbon emissions. Therefore, there may also be regulatory drivers or Corporate Social Responsibility (CSR) requirements which may temper a purely financial assessment.

\section{POSSIBLE CONFIGURATIONS OF LOW-ENTHALPY GEOTHERMAL SYSTEMS IN THE MINING INDUSTRY}

\section{Potential Heat Reservoirs}

Several configurations of geothermal systems are possible on mine sites, tapping into different types of heat reservoir. In practice, certain heat reservoirs are more likely to be exploitable at given phases of a mining project - exploration, operation and closure - and may have different levels of perceived risk associated with them. Based on a review of the current mining geothermal applications, there is also significant potential to harness geothermal energy from 'legacy' mines - older abandoned mines or mines where closure was not managed in line with modern aspirations. Potential applications are summarised in Table 2.

It is possible to install open loop or closed loop ground collectors in natural ground as shown on Figure 1. Such systems are little different to those applied widely outside the mining industry. Natural ground may have particular potential to provide heating and cooling to exploration camps, by making use of the exploration rigs to drill closed loop ground collectors. Conventional ground collectors can also be installed to extract heat from mine waste dumps, including the heat generated by geochemical reactions therein (Banks et al. 2004).

Where dewatering pumping is carried out for underground or open pit mines (Figure 2), either during operation or as part of a managed closure regime, it is a fairly straightforward modification to pass the water through a heat transfer system configured to form an open loop geothermal system.

The review of existing mining geothermal systems summarised in Table 1 indicates that by far the most common application to date is the extraction of heat from flooded underground mine workings. Where there is a net abstraction of water, for example where pumping is used to control rebound of regional groundwater 
levels following closure, the water can be pumped out, passed through a heat transfer system and then disposed of to the surface water environment (Figure 3a). Where there is no requirement for net pumping of water, and an interconnected set of mine workings exists, it is possible to recirculate water through the workings, effectively using the mine workings as a huge ground collector (Figure 3b). Figure 3 shows the simplest arrangement for pumping from flooded underground mines, where pumps are installed directly in existing shafts; older shafts may be unstable and it may be necessary to install a perforated 'well liner' within the shaft to provide a clear and protected vertical void into which the pump can be installed. If the shafts are inaccessible, have collapsed or have been backfilled, the experience of the operational geothermal system at Heerlen in The Netherlands shows that it is possible to successfully drill boreholes into flooded roadways to extract/reinject water (Roijen 2011).

Pit lakes formed post-closure in open pit mines can also form a large heat reservoir, which can be exploited by either open loop or closed loop systems (Figure 4).

\section{Potential Environmental Impacts from Mining Geothermal Systems}

Geothermal systems can cause a range of environmental impacts, as shown in Table 3. In most cases the potential negative impacts can be mitigated by appropriate design. Further background on environmental impacts is given by Younger (2006).

\section{Potential Energy Demands}

During the exploration and operation phases, the most obvious use for heat energy is on the mine site itself. Most mine sites will contain site offices, accommodation buildings, equipment garages and workshops which may require heating or cooling. On-site heat demand will be near to the source (and so will not require transmission over great distances), and will typically be under the control of the operator. As a result the practicalities and commercial relationships will be straightforward.

In cold climates, in addition to mine camps, applications can include direct heating and ventilation air heating for portals, head houses, and other areas and systems prone to icing. Conversely, cooling may be needed for mine camps in many parts of the world or to chill ventilation air through deep hard rock mines to control working temperatures. Based on experience in other industries, and the likely energy scale of energy demand on mine sites, geothermal systems on mine sites are unlikely to be deployed to provide $100 \%$ of the heat energy to a given site. The most effective deployment is when geothermal systems are configured to supply part of the baseload heat demand of the site, with supplementary conventional systems operated to meet peak demands.

Allocating a potential value to on-site use of heat is straightforward, as the heat simply displaces the running cost of existing gas/electric/oil heaters or chillers in these applications. Based on experience with geothermal systems outside of the mining industry, heat energy from geothermal sources can have significantly lower unit costs compared to traditional fossil fuel sources.

The potential for off-site heat demand will vary significantly from site to site. Importantly, off-site demand will potentially continue to exist after the end of mine operations and following closure. The location of the potential heat demand has a significant influence on the feasibility of off-site use because it is difficult to transfer low grade heat energy (typically in the form of warm water) over long distances unless it is transmitted by well-engineered district heating systems. These allow a relatively small number of heat sources to feed into a heat network (typically comprising buried insulated pipes used to circulate warm water). It is relatively unusual for active mine sites to be located in densely populated areas, however, there are often significant communities nearby and there may be opportunities to provide heat to properties via district heating systems. Other potential heat uses are agricultural such as for glasshouse heating, produce drying, fish farm heating and other large scale uses of low temperature heat. Understanding the value of heat that can be provided to off-site 
users is more complicated as it will largely be dependent on the market value of heat in the locality, which may be variable with location and with the temperature of the supplied heat and can be difficult to accurately determine.

\section{Commercial Aspects}

Where mine operators use heat from ground energy systems to meet on-site demand, the commercial situation is straightforward as the heat energy from the ground energy system will replace heat from conventional sources used by the mine operator. However, where the operator intends to harness heat energy and export it to supply off-site demand the commercial situation may be more complex. While the sale of energy would potentially provide a new income stream, the downside is that there would be a need for commercial arrangements with those buying the energy, and systems for metering and billing are likely to be necessary. Where closed or legacy mines are exploited for heat energy these arrangements would have to continue after mining operations have ceased. In practice, it may be appropriate for the mine operator to become part of, or develop a relationship with, an 'energy supply company' (EsCo) to manage the sale and distribution of energy.

\section{CONCLUSION}

In 2013 there are less than 20 documented examples of operational mining geothermal systems worldwide. This is surprising, since the wide and increasing use of geothermal systems outside of the mining industry has proven that geothermal systems are reliable and can compete with, and often undercut, the costs of conventional fuels. On remote mine sites, where fuels may have to be shipped in over great distances, geothermal energy may have a significant advantage in operational cost. The potentially lower operational cost needs to be offset against the capital cost of setting up a geothermal system. The focus for mine operators should therefore be on identifying at feasibility stage those projects where conditions are favourable for geothermal systems, where the potential risks are understood, and where the economics are likely to be beneficial.

Almost all of the case histories listed in Table 1 are of the flooded underground workings type, at the closure or legacy stage of mine development. By definition these systems must be supplying off-site energy demands, beyond the mine itself. This highlights that geothermal systems offer both a potential new revenue stream for mine operators and a chance to contribute to Corporate Social Responsibility targets by supplying nearby communities with low carbon energy.

It is clear that there is a huge potential to use geothermal technology to exploit the heat energy in mines at all stages from exploration through to closure and beyond, by providing low carbon heat energy to displace some use of fossil fuels. The challenge for mine operators (and those responsible for legacy mines) is to identify, investigate and prioritise those mines sites where geothermal systems can be most effectively developed.

\section{REFERENCES}

Banks, D. 2012. An Introduction to Thermogeology: Ground Source Heating and Cooling, 2nd edition. Blackwell, Oxford.

Banks, D., Fraga Pumar, A. and Watson, I. 2009. The operational performance of Scottish minewater-based ground source heat pump systems. Quarterly Journal of Engineering Geology and Hydrogeology 42, 347-357.

Banks, D., Skarphagen, H., Wiltshire, R. and Jessop, C. 2004. Heat pumps as a tool for energy recovery from mining wastes. Energy, Waste and the Environment: a Geochemical Perspective (Gieré, R and Stille, P, eds.). Geological Society, London, Special Publication 236, 499-513. 
Brown, D. W., Duchane, D. V., Heiken, G. and Hriscu, V. Th. 2012. Mining the Earth's Heat: Hot Dry Rock

Geothermal Energy. Springer, Heidelberg, Germany.

Cashmore, G. 2011. Personal communication.

Coal Authority. 2011. Personal communication.

Dickson, M. H. and Fanelli, M 2003. Geothermal Energy: Utilisation and Technology. UNESCO, Paris.

Digges La Touche, G. and Preene, M. 2011. The potential use of ground energy in the mining industry exploration to closure. Proceedings of the 11th International Mine Water Association Congress - Mine Water - Managing the Challenges, Aachen, Germany, September 2011, 161-166.

Geothermal Heat Pump Consortium Inc. 1997. Municipal Building, Park Hills Missouri. GHPC \#CS-064 8/97. Geothermal Heat Pump Consortium Inc, Washington DC.

Ghomshei, M. 2007. Geothermal Energy from Con Mine for Heating the City of Yellowknife, NWT: A Concept Study. University of British Colombia, Vancouver.

Jensen, E. B. 1983. Mine water used to heat ventilation air at Henderson Molybdenum Mine. Mining Engineering 35(1), 17-20.

Jessop, A. M. 1995. Geothermal energy from old mines at Springhill, Nova Scotia, Canada. World Geothermal Congress Proceedings, Florence, 463-468.

Jessop, A. M., MacDonald, J. K. and Spence, H. 1995. Clean energy from abandoned mines at Springhill, Nova Scotia. Energy Sources 17, 93-106.

Loredo, J., Ordóñez, A., Jardón, S. and Álvarez, R. 2011, Mine water as geothermal resource in Asturian coal mining basins (NW Spain). Proceedings of the 11th International Mine Water Association Congress - Mine Water - Managing the Challenges, Aachen, Germany, September 2011, 177-182.

Malolepszy, Z., Demollin-Schneiders, E. and Bowers, D. 2005. Potential use of geothermal mine waters in Europe. Proceedings World Geothermal Congress 2005, Antalya, Turkey, April 2005.

Matthes, R. and Schreyer, J. 2007. Remediation of the Old Wismut shaft 302 in Marienberg and installation of a technical plant for geothermic mine water use (Ore Mountains, Germany). Proceedings of the International Mine Water Association Symposium - Water in Mining Environments, Cagliari, Italy, May 2007, $227-231$.

Parker, K. 2011. Potential for heat pumps in Yorkshire and the rest of the United Kingdom. Heat Pump Technology Using Minewater (Faull, M L, ed.). National Coal Mining Museum for England Publications, Overton, UK, 32-42.

Popielak, R., Moreno, .J and Striegl, A. 2013. Design of a dewatering system for a geothermally influenced underground gold mine. Mine Water Solutions in Extreme Environments, Chapter 5: Extremely Complex Hydrogeology, April 2013, Lima, Peru, 538-548.

Raymond, J., Therrien, R. and Hassani, F. 2008. Overview of geothermal energy resources in Québec (Canada) mining environments. Proceedings of the 10th International Mine Water Association Congress - Mine Water and the Environment, Karlsbad, Czech Republic, 99-112. 
Roijen, E. 2011. The use of an open-loop heat-pump system to heat social housing and an office building throughout the town of Heerlen, the Netherlands. Heat Pump Technology Using Minewater (Faull, M L, ed.). National Coal Mining Museum for England Publications, Overton, 15-25.

Wang, F, Maidment, G G, Ford, A, Barker, N, and Missenden, J F (2007). Ground source heating and cooling in the UK. Proceedings of the Institute of Refrigeration 2006-7, 6.1-6.16.

Wieber, G. H. E., and Pohl, S. 2008. Mine water: a source of geothermal energy - examples from the Rheinish Massif. Proceedings of the 10th International Mine Water Association Congress - Mine Water and the Environment, Karlsbad, Czech Republic, 113-116.

Wieber, G. H. E., Deckert, H., Enzmann, F. and Kersten, M. 2012. Heat storage potential of a flooded mine in the Siegerland-Wied district, Germany. Proceedings of the International Mine Water Association Symposium - Mine Water and the Environment, Perth, Australia, 459-463.

Williamson, S. and Vogwill, R. I. J. 2001. Dewatering in the hot groundwater conditions at Lihir Gold. Proceedings of the International Mine Water Association Symposium, Belo Horizonte, Brazil.

Younger, P. L. 2006. Potential pitfalls for water resources of unregulated development of ground-source heat resources. Proceedings of the Annual Conference of the Chartered Institution of Water \& Environmental Management. Sept 13th - 15th 2006, Newcastle upon Tyne, UK. [unpaginated CD publication]. 
Table 1 - Documented examples of low-enthalpy geothermal systems used to exploit energy from mines

\begin{tabular}{|c|c|c|c|}
\hline $\begin{array}{l}\text { Approximate } \\
\text { date of } \\
\text { implementatio } \\
\text { n }\end{array}$ & Location & Description & $\begin{array}{l}\text { Reference } \\
\text { s }\end{array}$ \\
\hline Early 1980s & $\begin{array}{l}\text { USA - Henderson } \\
\text { molybdenum mine, } \\
\text { Empire, Colorado, } \\
\text { USA }\end{array}$ & $\begin{array}{l}\text { Minewater at } 29^{\circ} \mathrm{C} \text { is used for direct heating of mine } \\
\text { ventilation air to prevent icing of shafts and } \\
\text { equipment and to control mine working } \\
\text { temperatures. Water is used at a rate of } 72 \mathrm{l} / \mathrm{s}\end{array}$ & $\begin{array}{l}\text { Jenson } \\
1983\end{array}$ \\
\hline 1984 & $\begin{array}{l}\text { Germany - Heinrich } \\
\text { coal mine, Heisingen, } \\
\text { Essen }\end{array}$ & $350 \mathrm{~kW}$ capacity, used to heat nursing home & $\begin{array}{l}\text { Wieber } \\
\text { and Pohl } \\
2008\end{array}$ \\
\hline Late 1980 s & $\begin{array}{l}\text { Canada - Springhill, } \\
\text { Nova Scotia }\end{array}$ & $\begin{array}{l}\text { The source is flooded underground coal mine } \\
\text { workings. Minewater at } 18^{\circ} \mathrm{C} \text { supplied to heat pumps } \\
\text { used to heat and cool several buildings including } \\
\text { manufacturing facilities and a restaurant. Reported } \\
\text { data from } 1989-1990 \text { show peak daily averaged } \\
\text { heating rate of } 111 \mathrm{~kW} \text { and peak daily averaged } \\
\text { cooling rate of } 159 \mathrm{~kW}\end{array}$ & $\begin{array}{l}\text { Jessop } \\
1995 ; \\
\text { Jessop et } \\
\text { al } 1995\end{array}$ \\
\hline $\begin{array}{l}\text { Approximately } \\
1994\end{array}$ & $\begin{array}{l}\text { Germany - abandoned } \\
\text { tin mine, } \\
\text { Ehrenfriedersdorf, } \\
\text { Sachsen }\end{array}$ & Used to heat a high school & $\begin{array}{l}\text { Wieber } \\
\text { and Pohl } \\
2008\end{array}$ \\
\hline 1995 & $\begin{array}{l}\text { USA - Park Hills, } \\
\text { Missouri }\end{array}$ & $\begin{array}{l}\text { Production bore } 120 \mathrm{~m} \text { deep penetrating to a flooded } \\
\text { lead mine. Water pumped at } 14^{\circ} \mathrm{C} \text {, flow } 5 \mathrm{l} / \mathrm{s} \text {, } \\
\text { supplying nine heat pumps of individual capacity } \\
\text { between } 5 \text { and } 18 \mathrm{~kW} \text { each. Used to heat and cool a } \\
750 \mathrm{~m}^{2} \text { Municipal Building. Water is returned to the } \\
\text { mine via a second borehole }\end{array}$ & $\begin{array}{l}\text { Geothermal } \\
\text { Heat Pump } \\
\text { Consortium } \\
\text { Inc. } 1997\end{array}$ \\
\hline $\begin{array}{l}\text { Approximately } \\
1997\end{array}$ & $\begin{array}{l}\text { Germany - abandoned } \\
\text { tin mine, } \\
\text { Ehrenfriedersdorf, } \\
\text { Sachsen }\end{array}$ & $\begin{array}{l}82 \mathrm{~kW} \text { capacity, used to heat a museum building for } \\
\text { mine visitors }\end{array}$ & $\begin{array}{l}\text { Wieber } \\
\text { and Pohl } \\
2008\end{array}$ \\
\hline 1998 & $\begin{array}{l}\text { Norway - Folldal } \\
\text { Mine, Hedmark } \\
\text { County }\end{array}$ & $\begin{array}{l}\text { Underground cavern in disused mine is heated by a } \\
\text { closed loop ground collector in a } 600 \mathrm{~m} \text { deep flooded } \\
\text { shaft. } 18 \mathrm{~kW} \text { of heat effect is produced by a heat pump }\end{array}$ & $\begin{array}{l}\text { Banks et } \\
\text { al } 2004\end{array}$ \\
\hline 1999 & $\begin{array}{l}\text { UK - Shettleston, } \\
\text { Scotland }\end{array}$ & $\begin{array}{l}100 \mathrm{~m} \text { deep borehole drilled into flooded } \\
\text { underground coal mine workings. Minewater at } 12^{\circ} \mathrm{C} \\
\text { supplied to heat pumps of rated capacity } 65 \mathrm{~kW} \text {, } \\
\text { producing hot water at } 55^{\circ} \mathrm{C} \text {. Used for space heating } \\
\text { and pre-heating of domestic hot water for } 16 \\
\text { residential properties }\left(1,600 \mathrm{~m}^{2} \text { total) residential }\right. \\
\text { properties. Minewater re-injected via a shallower } \\
\text { borehole (50-60 m deep) }\end{array}$ & $\begin{array}{l}\text { Banks et al } \\
2009\end{array}$ \\
\hline
\end{tabular}




\begin{tabular}{|c|c|c|c|}
\hline $\begin{array}{l}\text { Approximate } \\
\text { date of } \\
\text { implementatio } \\
\text { n }\end{array}$ & Location & Description & $\begin{array}{l}\text { Reference } \\
\mathrm{s}\end{array}$ \\
\hline 2000 & $\begin{array}{l}\text { UK - Lumphinans, } \\
\text { Scotland }\end{array}$ & $\begin{array}{l}172 \mathrm{~m} \text { deep borehole drilled into flooded } \\
\text { underground coal mine workings. Minewater at } 15^{\circ} \mathrm{C} \\
\text { supplied to heat pumps of rated capacity } 65 \mathrm{~kW} \text {, } \\
\text { producing hot water at } 55^{\circ} \mathrm{C} \text {. Used for space heating } \\
\text { and pre-heating of domestic hot water for } 16 \\
\text { residential properties }\left(1,600 \mathrm{~m}^{2} \text { total }\right) \text { residential } \\
\text { properties. Minewater re-injected via a shallower } \\
\text { borehole (50-60 m deep) }\end{array}$ & $\begin{array}{l}\text { Banks et al } \\
2009\end{array}$ \\
\hline 2000 & $\begin{array}{l}\text { Germany - } \\
\text { Zollverein coal mine, } \\
\text { Katernberg, Essen }\end{array}$ & Used to heat a school of design & $\begin{array}{l}\text { Wieber } \\
\text { and Pohl } \\
2008\end{array}$ \\
\hline 2005 & $\begin{array}{l}\text { Norway - Kongsberg } \\
\text { Mine }\end{array}$ & $\begin{array}{l}\text { Closed loop system installed in a mine shaft } 250 \mathrm{~m} \\
\text { deep }\end{array}$ & $\begin{array}{l}\text { Banks et } \\
\text { al } 2004\end{array}$ \\
\hline 2006 & $\begin{array}{l}\text { Canada - Goyer } \\
\text { Quarry, Saint-Bruno- } \\
\text { De-Montarville, } \\
\text { Quebec }\end{array}$ & $\begin{array}{l}\text { Open loop system in a flooded open pit, feeding heat } \\
\text { pump units, with individual capacity ranging from } \\
3.6 \text { to } 5.3 \mathrm{~kW} \text {, installed in each of } 36 \text { apartments, for } \\
\text { a total heated area of } 6,039 \mathrm{~m}^{2}\end{array}$ & $\begin{array}{l}\text { Raymond } \\
\text { et al } 2008\end{array}$ \\
\hline 2007 & $\begin{array}{l}\text { Germany - Shaft } \\
\text { 302, Marienberg } \\
\text { Mine, Sachsen }\end{array}$ & $\begin{array}{l}\text { Minewater at } 12^{\circ} \mathrm{C} \text { is extracted at a rate of up to } 33 \\
\mathrm{l} / \mathrm{s} \text { from a } 144 \mathrm{~m} \text { deep shaft in a disused uranium } \\
\text { mine. Water is passed through plate heat exchangesrs } \\
\text { located on a platform at } 105 \mathrm{~m} \text { depth. The system has } \\
\text { a heating capacity of } 690 \mathrm{~kW} \text { and is used to heat a } \\
\text { swimming pool }\end{array}$ & $\begin{array}{l}\text { Matthes } \\
\text { and } \\
\text { Schreyer } \\
2007\end{array}$ \\
\hline 2008 & $\begin{array}{l}\text { UK - Mount } \\
\text { Wellington Mine, } \\
\text { Cornwall }\end{array}$ & $\begin{array}{l}\text { Closed loop system suspended in a former mine shaft } \\
\text { of an abandoned tin mine, heating the factory and } \\
\text { offices of Kensa Engineering. } 20 \mathrm{~kW} \text { Capacity. }\end{array}$ & $\begin{array}{l}\text { Cashmore } \\
2011\end{array}$ \\
\hline $\begin{array}{l}\text { Approximately } \\
2009\end{array}$ & $\begin{array}{l}\text { Russia - } \\
\text { Novoshaktinsk }\end{array}$ & Three wells, up to $400 \mathrm{~m}$ deep supplying heat pumps. & $\begin{array}{l}\text { Roijen } \\
2011\end{array}$ \\
\hline $\begin{array}{l}\text { Approximately } \\
2009\end{array}$ & $\begin{array}{l}\text { The Netherlands - } \\
\text { Heerlen }\end{array}$ & $\begin{array}{l}\text { The source is an flooded underground coal mine. } \\
\text { Deep minewater }\left(28^{\circ} \mathrm{C}\right) \text { is pumped for heating use } \\
\text { and shallow minewater }\left(18^{\circ} \mathrm{C}\right) \text { for cooling use. Water } \\
\text { is returned to mineworkings after use. Mine water is } \\
\text { supplied to a district heating energy station which } \\
\text { contains heat pumps of total rated capacity } \\
\text { approiximately } 700 \mathrm{~kW} \text {. District heating system is } \\
\text { used to supply office buildings and social housing } \\
\text { apartments. Heat pumps are augmented by } \\
\text { condensing gas boilers when needed. }\end{array}$ & $\begin{array}{l}\text { Roijen } \\
2011\end{array}$ \\
\hline $\begin{array}{l}\text { Approximately } \\
2010\end{array}$ & Spain - Hunosa & $\begin{array}{l}\text { Pumping system installed in shaft at mine closure } \\
\text { stage and used to cool university buildings }\end{array}$ & $\begin{array}{l}\text { Roijen } \\
\text { 2011; } \\
\text { Loredo }\end{array}$ \\
\hline
\end{tabular}




\begin{tabular}{llll}
\hline $\begin{array}{l}\text { Approximate } \\
\text { date of } \\
\text { implementatio } \\
\text { n }\end{array}$ & Location & Description & $\begin{array}{l}\text { Reference } \\
\text { s }\end{array}$ \\
\hline 2011 & $\begin{array}{l}\text { UK - Dawdon, } \\
\text { County Durham }\end{array}$ & $\begin{array}{l}\text { Open loop system tapping into existing pumped flow } \\
\text { from disused coal mine, used as demonstration } \\
\text { system to heat buildings at existing Coal Authority } \\
\text { pumping station. 12 kW capacity. }\end{array}$ & Auth \\
& & & \\
\hline
\end{tabular}


Table 2 - Potential Applications of geothermal systems on mining projects

\begin{tabular}{|c|c|c|c|c|c|}
\hline & \multicolumn{5}{|c|}{ Heat reservoir } \\
\hline & Natural ground & $\begin{array}{c}\text { Backfilled } \\
\text { workings }\end{array}$ & Mine waste & $\begin{array}{c}\text { Dewatering } \\
\text { pumping }\end{array}$ & $\begin{array}{c}\text { Flooded } \\
\text { workings/pit } \\
\text { lakes }\end{array}$ \\
\hline \multicolumn{6}{|l|}{ Phase } \\
\hline Exploration & $\mathrm{X}$ & & & & \\
\hline Operation & $X$ & $\mathrm{X}$ & $X$ & $\mathrm{X}$ & \\
\hline Closure & & $\mathrm{X}$ & $X$ & $\mathrm{X}^{*}$ & $\mathrm{X}$ \\
\hline Legacy & & & & $\mathrm{X}^{*}$ & $X$ \\
\hline
\end{tabular}

Notes: * Where pumping is required as part of closure or environmental management measures 
Table 3 - Possible environmental impacts from geothermal systems on mine projects

\section{Potential Environmental Impact Key issues}

\section{Negative impacts}

Lowering of groundwater levels

Thermal impacts on surface water

Thermal impacts on groundwater

Chemical impacts on surface water from disposal of pumped water

Collapse of existing underground mine workings
Long term abstraction from open loop systems can lower regional groundwater levels and impact on community wells and groundwater dependent ecological features. Ground settlement due to effective stress increases may also be a concern.

Disposal to surface water bodies of warmer/cooler water from open loop systems can affect aquatic ecology in the receiving water body, because oxygen content of water is negatively correlated with temperature. Closed loop systems in pit lakes can have similar effects.

Disposal to groundwater of warmer/cooler water from open loop systems (where water is re-injected to aquifers or is recirculated in flooded working) can cause long term changes in groundwater temperature. This may cause geochemical changes which can affect water quality in the aquifer and potentially impact on any other (non-mining) geothermal systems in the area.

Disposal of water pumped from mines can cause pollution problems in the receiving water body due to precipitation of dissolved chemicals or release of dissolved gases.

Pumping from flooded mine workings for geothermal purposes will potentially change the water pressures and direction and velocity of water flow within the workings. This could lead to scour and or instability of the workings. If boreholes are drilled into workings for the purposes of water extraction/injection this can also have a destabilising effect.
Geothermal energy has lower greenhouse gas emissions than the fossil fuels it will displace

Geothermal energy has lower greenhouse gas emissions than the fossil fuels it will displace

In many remote areas and developing countries access to reliable energy sources is limited, and this can act as a constraint on local communities and industries 


\section{Appendix 1: Geothermal calculations: Heat energy potential of pumped or flowing water}

Where there is a flow of water (such as from a dewatering system) heat can be exchanged with the water to provide heating or cooling. If heating is to be provided, heat must be extracted from the flowing water, and the temperature of the water will be reduced by $\Delta \mathrm{T}$. Conversely, if cooling is to be provided, heat must be added to the flowing water, and the temperature of the water will be increased by $\Delta \mathrm{T}$.

Where the geothermal system operates in direct heating or cooling, for example using heat exchangers without the use of heat pumps, the heat energy $H$ (in $\mathrm{kW}$ ) which can be extracted from a stream of flowing water is:

$$
H=Q \cdot \rho_{w} \cdot S_{w} \cdot \Delta T
$$

where $Q$ is the total groundwater flowrate from the system $\left(\mathrm{m}^{3} / \mathrm{s}\right), \rho_{w}$ is the density of water $\left(1000 \mathrm{~kg} / \mathrm{m}^{3}\right), S_{w}$ is the heat capacity of water $(4.2 \mathrm{~kJ} / \mathrm{kg} / \mathrm{K})$. Equation (1) shows that using a $\Delta T$ of $5 \mathrm{~K}$, every $100 \mathrm{~kW}$ of heating or cooling requires around 5 litres $/ \mathrm{s}\left(0.005 \mathrm{~m}^{3} / \mathrm{s}\right)$ of groundwater flow, so $1 \mathrm{MW}$ of heating or cooling would require a peak water flow of around 50 litres $/ \mathrm{sec}\left(0.05 \mathrm{~m}^{3} / \mathrm{s}\right)$.

Where a heat pump is used, the energy used to drive the heat pump, and the efficiency of operation the heat pump must be taken into account. The efficiency of a heat pump is normally referred to as its coefficient of performance (COP), which is normally expressed as the ratio of the heat energy delivered to the electrical energy used to drive the heat pumps. The COP delivered by a given heat pump will depend on the relative input and output temperatures, but in normal operation COPs in the range 3 to 6 are typical.

Where a heat pump is used to provide heating, the heat associated with the motor driving the heat pump will contribute to the heat output from the system, so:

$$
H=\left(Q \cdot \rho_{w} \cdot S_{w} \cdot \Delta T\right) /(1-\lfloor 1 / C O P\rfloor)
$$

Where a heat pump is used to provide cooling, the heat associated with the motor driving the heat pump will act to reduce the available cooling output from the system, so:

$$
H=\left(Q \cdot \rho_{w} \cdot S_{w} \cdot \Delta T\right) /(1+\lfloor 1 / C O P\rfloor)
$$

\section{Note on sustainable rates of heat extraction of an underground reservoir}

The available quantity of heat from a reservoir is the total heat resource. A key design issue is the rate at which heat is extracted from (for heating applications) or added to (for cooling systems) the reservoir by the geothermal system. The initial temperature of an underground heat reservoir is the result of the natural heat inputs and outputs to the reservoir, from a range of sources including solar energy falling on the ground surface, geothermal flux from depth and associated with groundwater flow moving between aquifers and between strata. If a geothermal system adds or removes heat at a rate significantly greater than the natural replenishment then, over time, the temperature the of heat reservoir will change significantly - falling for 
heating dominated applications and rising for cooling dominated applications. In some circumstances, these changes in reservoir temperature may not cause significant problems. However, any significant changes in reservoir temperature creates the potential for adverse environmental impacts and, in the long term, may cause the reservoir temperature to cross a cut-off temperature beyond which the chosen geothermal technology will not function efficiently.

\section{Notation}

COP - Coefficient of performance of heat pump / Dimensionless

$H$ - Potential heat output from geothermal system / kW

$Q$ - Groundwater flowrate from open loop system $/ \mathrm{m}^{3} / \mathrm{s}$

$S_{w}$ - Specific heat capacity of water $/ \mathrm{kJ} / \mathrm{kg} / \mathrm{K}$

$\Delta T$ - Differential temperature / $\mathrm{K}$

$\rho_{w}$ - Density of water $/ \mathrm{kg} / \mathrm{m}^{3}$ 
LIST OF FIGURES (Submitted as separate files)

Figure 1 - Conceptual Sections through geothermal systems

a) Open loop

b) Closed loop

Figure 2 Potential Geothermal Systems in Dewatered Mines

a) Underground mines

b) Open pit mines

Figure 3 Potential Geothermal Systems in Flooded underground mines

a) Pumping to waste

b) Pumping and reinjection

Figure 4 Potential Geothermal Systems in Pit lakes

a) Open loop

b) Closed loop 

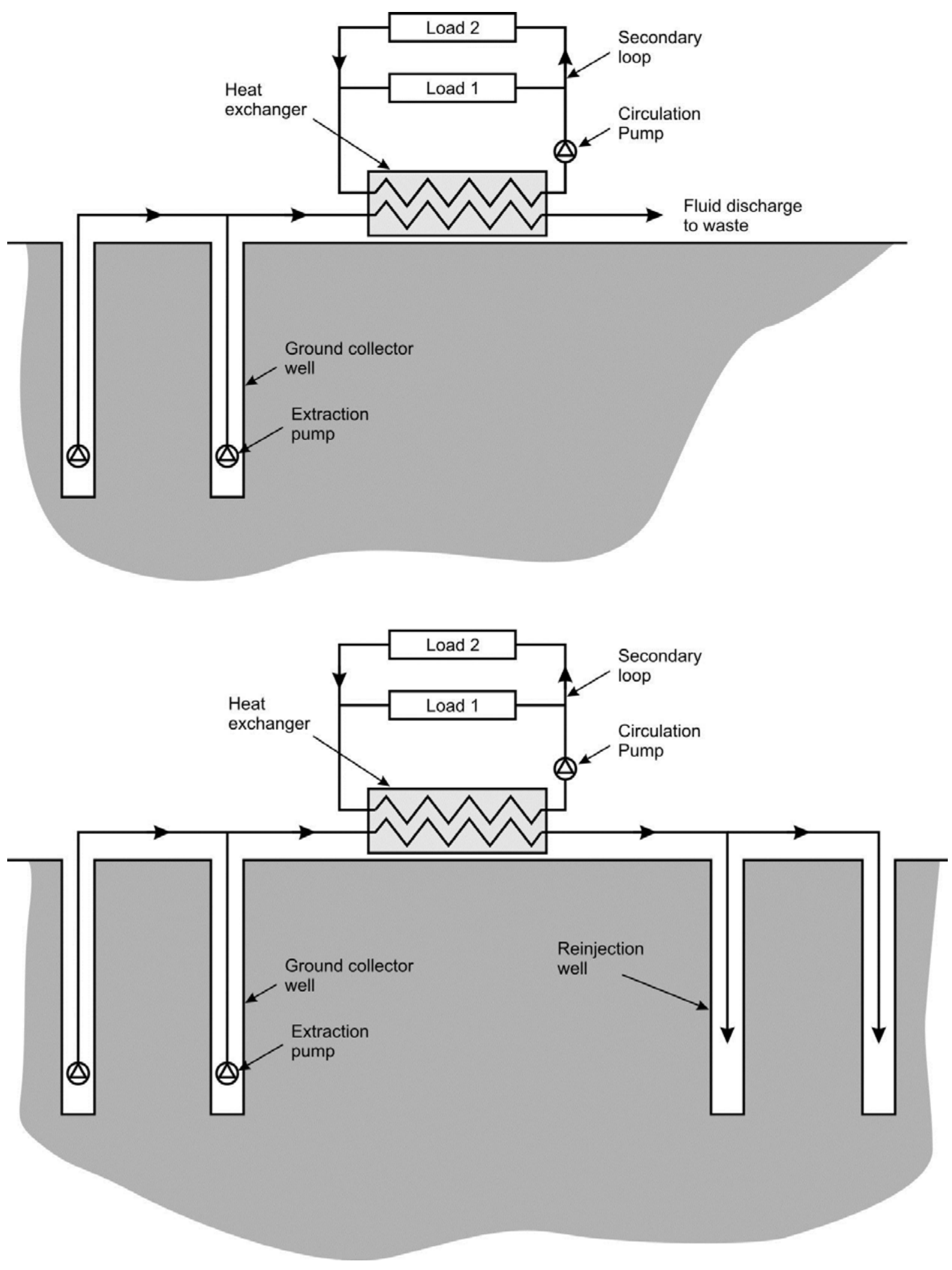


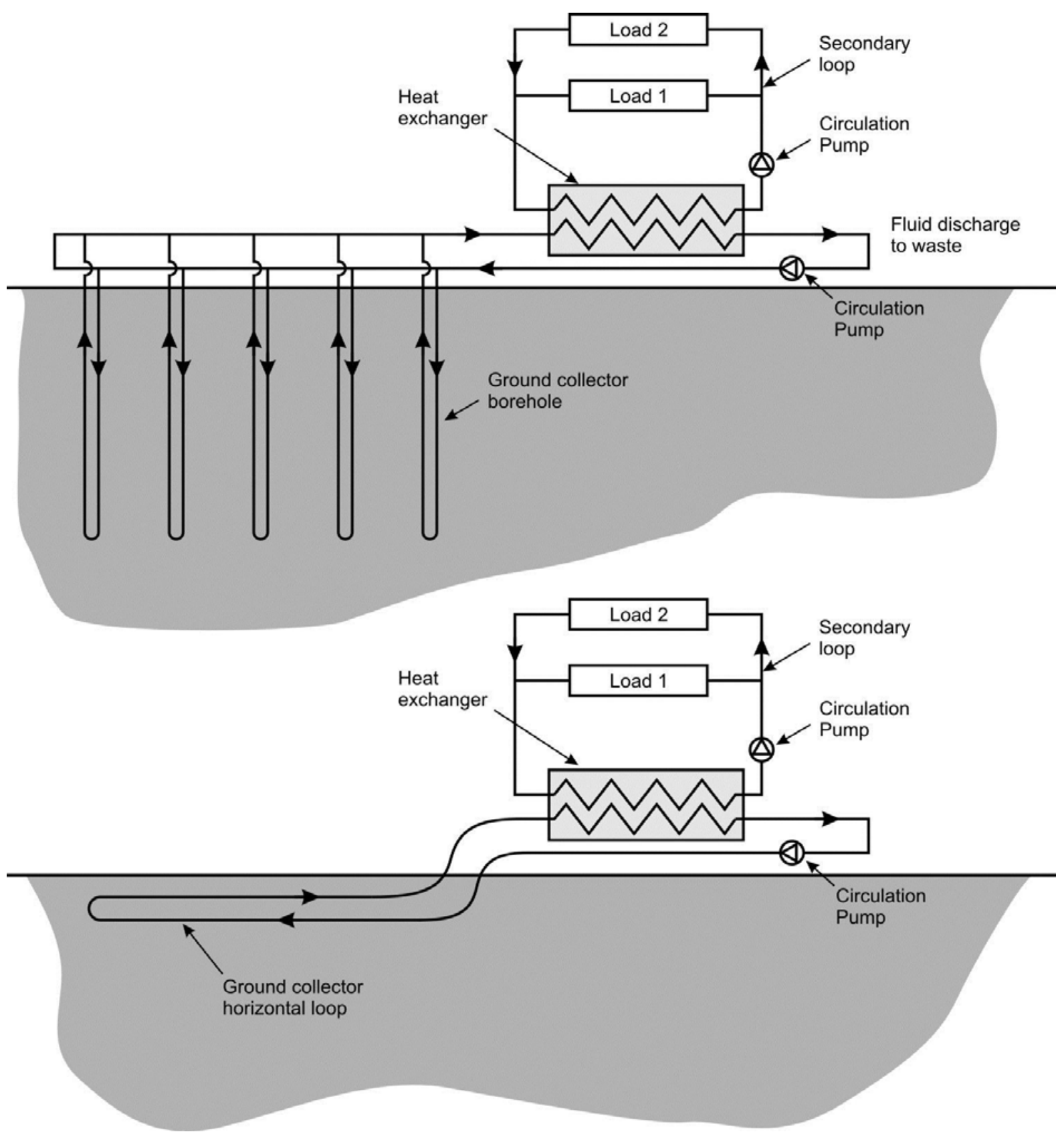



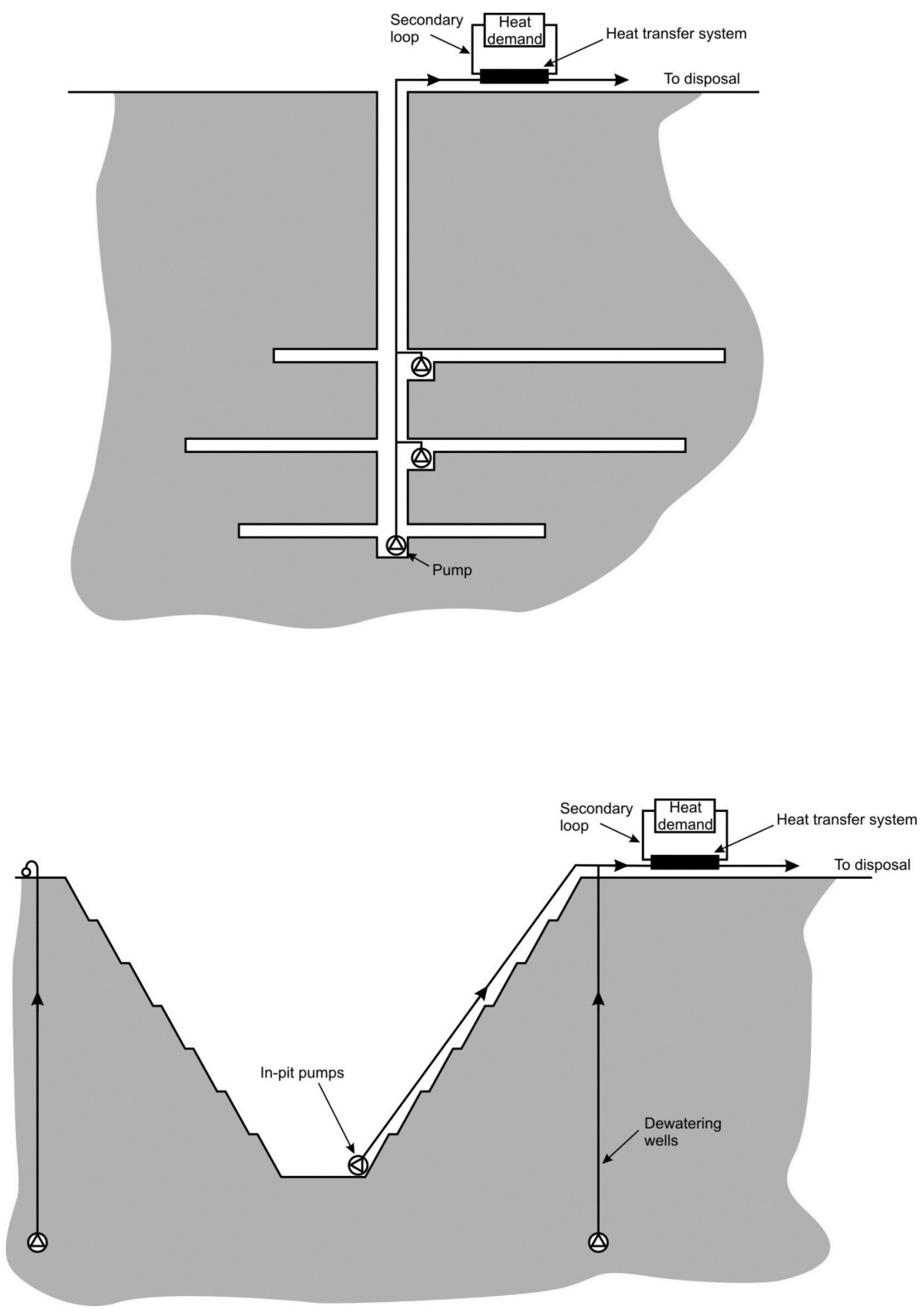

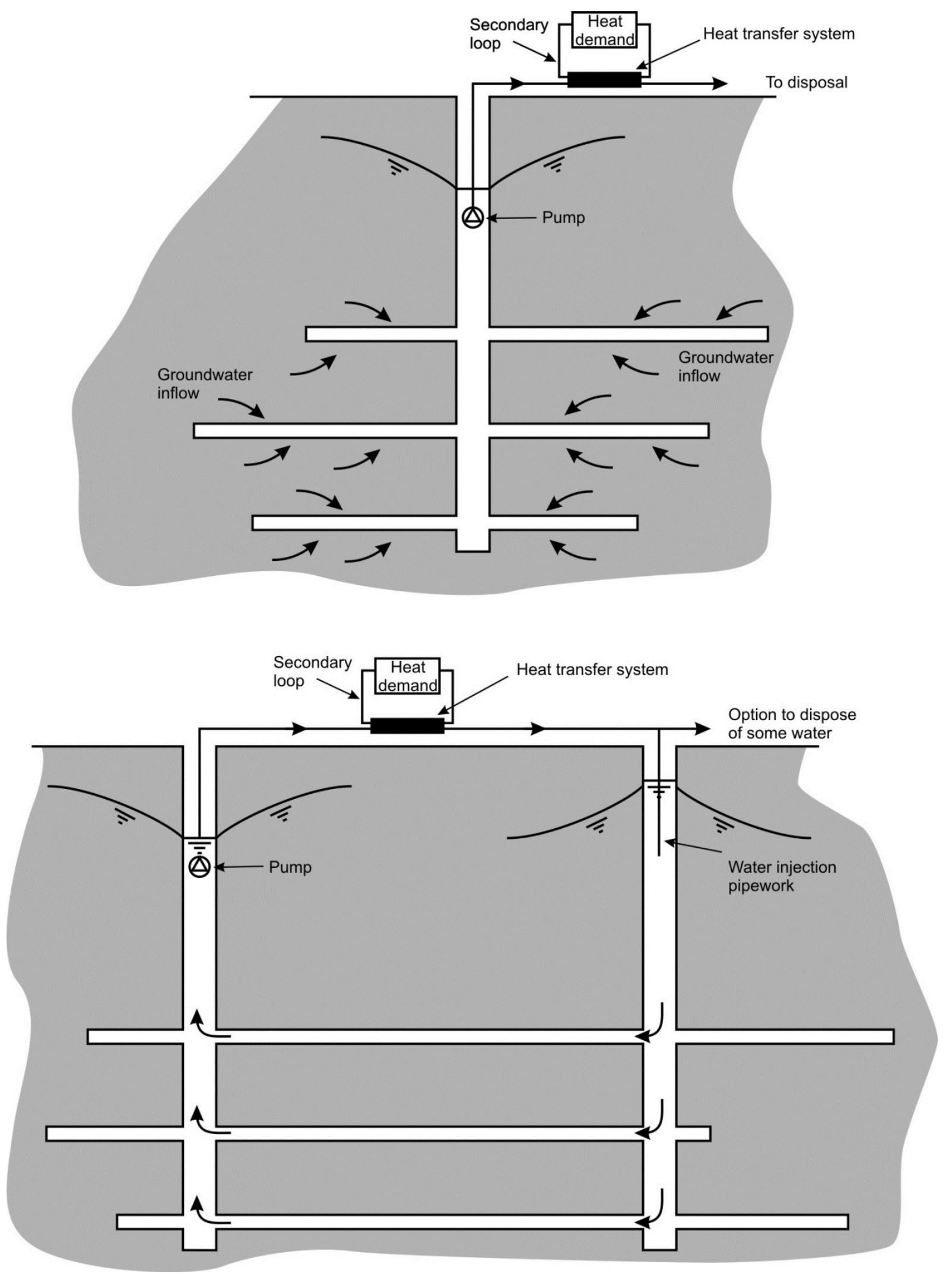

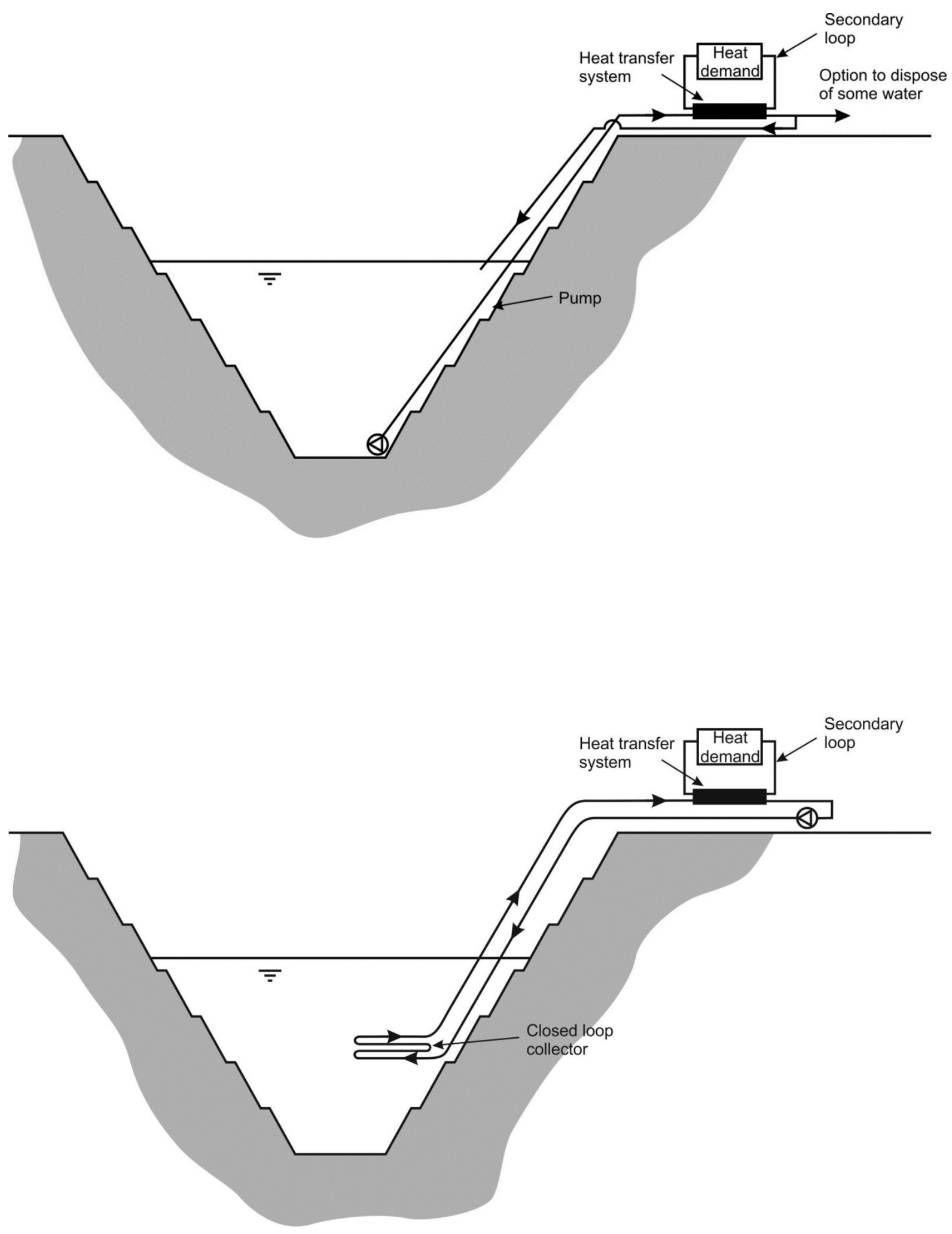